\title{
Directed-Spray Application of Paraquat and Diuron in Physic Nut Plants ${ }^{1}$
}

\author{
Aplicação de Paraquat e Diuron em Jato Dirigido em Pinhão-Manso \\ COSTA, N.V. ${ }^{2}$, NEUNFELD, T.H. ${ }^{2}$, OHLAND, T.2 ${ }^{2}$ PIANO, J.T. ${ }^{2}$, and KLEIN, J. ${ }^{2}$
}

\begin{abstract}
There is little information about the selectivity of herbicides in physic nut (Jatropha curcas) in Brazil. Therefore, this study aimed to evaluate the selectivity of different doses and mixtures of paraquat and diuron in direted-spray applications in physic nut plants in greenhouse conditions. The study used a randomized block design, with five replicates. The treatments were: paraquat (200 and $\left.600 \mathrm{~g} \mathrm{ha}^{-1}\right)$, diuron $\left(1,000\right.$ and 2,000 $\left.\mathrm{g} \mathrm{ha}^{-1}\right)$, paraquat + diuron $\left(200+1,000 \mathrm{~g} \mathrm{ha}^{-1}\right)$, paraquat + diuron $\left(200+2,000 \mathrm{~g} \mathrm{ha}^{-1}\right)$, paraquat + diuron $(600+$ $\left.1,000 \mathrm{~g} \mathrm{ha}^{-1}\right)$, paraquat + diuron $\left(600+2,000 \mathrm{~g} \mathrm{ha}^{-1}\right)$ and a control (no application). Directedspray application was performed at 70 days after sowing by the lower third of the plants. The treatments of diuron and paraquat + diuron mixtures affected the growth and photosynthetic activity of physic nut plants, injuries being more pronounced at doses of diuron of 2,000 $\mathrm{g} \mathrm{ha}^{-1}$, while the isolated application of paraquat at doses of 200 and $600 \mathrm{~g} \mathrm{ha}^{-1}$ showed good selectivity potential for physic nut plants.
\end{abstract}

Keywords: Jatropha curcas, weed, chemical control, gas exchange.

RESUMO - Existem poucas informações sobre herbicidas seletivos para a cultura do pinhão-manso (Jatropha curcas) no Brasil. Dessa forma, objetivou-se com este trabalho avaliar a seletividade de diferentes doses e misturas de paraquat e diuron em aplicações dirigidas nas plantas de pinhãomanso. Utilizou-se o delineamento experimental de blocos casualizados com cinco repetições. Os

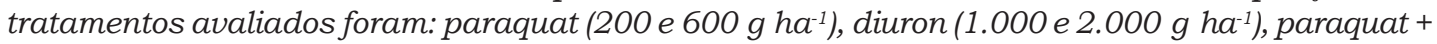
diuron $\left(200+1.000 \mathrm{~g} \mathrm{ha}^{-1}\right)$, paraquat + diuron $\left(200+2.000 \mathrm{~g} \mathrm{ha}^{-1}\right)$, paraquat + diuron $\left(600+1.000 \mathrm{~g} \mathrm{ha}^{-1}\right)$, paraquat + diuron $\left(600+2.000 \mathrm{~g} \mathrm{ha}^{-1}\right)$ e uma testemunha (sem aplicação). A aplicação foi realizada aos 70 dias após a semeadura, em jato dirigido na região do terço inferior das plantas. Os tratamentos de diuron e as misturas paraquat + diuron afetaram o crescimento e a atividade fotossintética das plantas de pinhão-manso, sendo as injúrias mais acentuadas nas doses de diuron de $2.000 \mathrm{~g} \mathrm{ha}^{-1}$. Enquanto que a aplicação isolada do paraquat nas doses de 200 e $600 \mathrm{~g} \mathrm{ha}^{-1}$ apresentaram bom potencial de seletividade para plantas de pinhão-manso.

Palavras-chave: Jatropha curcas, planta daninha, controle químico, trocas gasosas.

\section{INTRODUCTION}

The hysic nut (Jatropha curcas), which belongs to the family Euphorbiaceae, is an important oleaginous species for biodiesel production (Arruda et al., 2004). Oil content present in the seeds varies between 30 and $40 \%$, with annual production of $1,100-$ 1,700 L ha-1 (Nunes, 2007). The possibility of using physic nut oil in biodiesel production opens up prospects for expansion of palnting areas.

Even though the physic nut is already grown in Brazilian agriculture, farmers do not fully master the technology to grow this crop yet. For widespread use of this technology, several difficulties must be overcome, such

1 Recebido para publicação em 31.1.2013 e aprovado em 8.4.2013.

2 Centro de Ciências Agrárias, Universidade Estadual do Oeste do Paraná, Paraná, Brasil, <neumarcio.costa@unioeste.br>. 
as lack of knowledge about the genetics of the plant, the establishment of the planting season, the adaptability for each region, soil fertility and also information on weed control.

Young physic nut plants may suffer negative interference of the weed community, which can compromise their growth, vegetative development, seed production and, consequently, oil content (Fey et al., 2011). However, among the methods for weed management in perennial crops, the use of selective pre-emergent and postemergent herbicides, either alone or mixed, may be a great alternative, especially considering weed management in large areas (Erasmo et al., 2009).

According to Souza \& Melles (1986), mixtures of herbicides in the spray tank or in formulations are currently used to increase the spectrum of weed control or reduce costs by employing cheaper products or even by reducing doses due to synergistic responses which occur when two or more herbicides are mixed.

Oliveira et al. (2009) argue that the application of diuron in coffee seedlings provides satisfactory control of the species Commelina benghalensis, C. erecta and Tripogandra diuretica. Applying diuron at a dose of 2,400 $\mathrm{g} \mathrm{ha}^{-1}$ at $21 \mathrm{DAA}$, according to these authors, respectively provided control levels of $82.5,85.0$ and $72.5 \%$ for the species evaluated. Likewise, Christoffoleti et al. (2010) evaluated the mixture paraquat + diuron and found satisfactory effectiveness in the control of species of horseweed (Conyza spp.) between the two-leaf and the four-leaf stages in citrus until 42 DAA from the dose of $300 \mathrm{~g}$ ha $+150^{-1}$ of paraquat + diuron; when applied alone, paraquat was efficient from the dose of $300 \mathrm{~g} \mathrm{ha}^{-1}$.

However, particularly for the cultivation of the physic nut, there is little information on both the phytotoxic effect of formulations based on paraquat and diuron available in the market and the levels of herbicide tolerance of this crop. Thus, studies on the selectivity of paraquat and diuron are needed to provide further information on the use of these herbicides on physic nut crops.
According to Galon et al. (2010), because herbicides have different mechanisms of action, they may influence photosynthetic activity directly or indirectly. Thus, the damage caused by plant phytotoxicity can be more efficiently measured from the photosynthetic rate and variables associated with it, such as stomatal conductance, transpiration, internal $\mathrm{CO}_{2}$ concentration and water use efficiency. Consequently, this information can assist in the development of research on herbicide selectivity in economically important plants. Therefore, the hypotheses for this study are based on the fact that the selectivity of paraquat (inhibitor of photosystem I) and diuron (inhibitor of photosystem II) in physuc nut crops could be granted by directed-spray application of herbicides individually or mixed.

This study aimed to evaluate the selectivity of different doses and mixtures of paraquat and diuron in directed-spray applications on physic nut plants.

\section{MATERIAL AND METHODS}

The study was conducted at a nursery with a shade screen (50\% brightness). The experiment used a randomized block design with five replications. The treatments consisted of the following doses and mixtures of herbicides: paraquat (200 and $600 \mathrm{~g} \mathrm{ha}^{-1}$ ), diuron $\left(1,000\right.$ and $\left.2,000 \mathrm{~g} \mathrm{ha}^{-1}\right)$, paraquat + diuron $\left(200+1,000 \mathrm{~g} \mathrm{ha}^{-1}\right)$, paraquat + diuron $\left(200+2,000 \mathrm{~g} \mathrm{ha}^{-1}\right)$, paraquat + diuron $(600+$ $\left.1,000 \mathrm{~g} \mathrm{ha}^{-1}\right)$, paraquat + diuron $(600+$ 2,000 $\mathrm{g} \mathrm{ha}^{-1}$ ) and a control without herbicide application.

Physic nut seeds were sown on January $1^{\text {st }}, 2011$. Five seeds were sown in each plastic pot, whose capacity was $17.81 \mathrm{dm}^{3}$. Thinning was performed at 15 days after sowing (DAS), and only one plant was left in each pot. These were the physical properties of the soil used: $143 \mathrm{~g} \mathrm{~kg}^{-1}$ clay, $35.95 \mathrm{~g} \mathrm{~kg}^{-1}$ silt and $821.05 \mathrm{~g} \mathrm{~kg}^{-1}$ sand. The chemical analysis provided the following $\mathrm{pH}$ values: $\mathrm{CaCl}_{2}=4.85$, $\mathrm{MO}=6.15 \mathrm{~g} \mathrm{dm}^{-3}, \mathrm{P}$ (extractor) $=29.93 \mathrm{~g} \mathrm{dm}^{-3}$, $\mathrm{K}$ (extractor) $=0.10 \mathrm{cmol}_{\mathrm{c}} \mathrm{dm}^{-3}, \mathrm{Ca}=$ $0.95 \mathrm{cmol}_{\mathrm{c}} \mathrm{dm}^{-3} ; \mathrm{Mg}=0.29 \mathrm{cmol}_{\mathrm{c}} \mathrm{dm}^{-3} ; \mathrm{Al}^{3+}=$ $0.20 \mathrm{cmol}_{\mathrm{c}} \mathrm{dm}^{-3} ; \mathrm{CTC}=4.48 \mathrm{cmol}_{\mathrm{c}} \mathrm{dm}^{-3}$, and $\mathrm{V} \%$ $=29.91 \%$. The soil was adjusted to $60 \%$ base saturation, and remained in plastic bags for 
an incubation period of approximately 15 days before sowing. The nitrogen fertilization was performed at 15 and 30 DAS, using $11.6 \mathrm{~g}$ of urea per pot. The recommended soil correction and fertilization was based on the castor bean, which belongs to the same family (Raij et al., 1997).

Directed-spray herbicide application was performed at 70 DAS by the lower third of the plants. The plants were arranged linearly, spaced at $1 \mathrm{~m}$, and the herbicide was applied along both sides of the plants.

The application was performed with a $\mathrm{CO}_{2}$ pressurized backback sprayer outfitted with spray nozzles (Jacto F110/0-8/3; 110/ $\mathrm{LD} / 02$, with pressure of $22 \mathrm{Lb}$ inches ${ }^{2}$ and calibrated to provide a flow rate of $200 \mathrm{~L} \mathrm{ha}^{-1}$. The environmental conditions were suitable for the application, with a temperature of $25{ }^{\circ} \mathrm{C}$, relative humidity of $70 \%$ and wind speed of $6 \mathrm{~km} \mathrm{~h}^{1}$.

Plant height $(\mathrm{cm})$ was measured with the a ruler, and stem diameter $(\mathrm{cm})$, with a precision caliper of $0.01 \mathrm{~mm}$, based on the height of $10 \mathrm{~cm}$ from the ground. The measurements were performed at $0,7,14,21$, 28 and 35 days after herbicide application (DAA).

Herbicide-induced plant phytotoxicity was visually assessed at 7, 14, 21, 28 and 35 DAA, using a percentage score scale, where 0 corresponded to no intoxication and 100 to plant death (SBCPD, 1995), taking into account growth inhibition, amount and uniformity of injuries, leaf abscission and sprouting capacity of plants.

The dry mass (g) of leaves, stem and root as well as total dry weight of the plant material was assessed t 35 DAA. The material was collected, placed in paper bags and taken to the oven at $65^{\circ} \mathrm{C}$ until constant weight. Leaf area $(\mathrm{cm} 2)$ was measured with a LI-3100C Portable Leaf Area Meter, and an analysis was made of all the leaves whose main vein were more than $3 \mathrm{~cm}$ long.

Gas exchange was assessed by sampling the third fully expanded leaf from the apex of the plant. A LI-6400XT (Licor Inc. Lincoln, NE) infra-red gas analyzer was used to determine the rate of net photosynthesis (A), stomatal conductance $\left(\mathrm{g}_{\mathrm{s}}\right)$, transpiration $(\mathrm{E})$, internal $\mathrm{CO}_{2}$ concentration $\left(\mathrm{C}_{\mathrm{i}}\right)$ and water-use efficiency $(\mathrm{WUE}=\mathrm{A} / \mathrm{E})$.

Gas exchange measurements were performed on sunny days, between 8:00 and 10:00 a.m. at 8, 16, 23 and 31 DAA. The photosynthetically active photon flux during gas exchange measurements was $1.800 \pm$ $0.88 \mathrm{~mol} \mathrm{~m}^{-2} \mathrm{~s}^{-1}$.

At 35 DAA, the same leaf previously collected to measure gas exchange was used to determine the concentrations $\left(\mu \mathrm{g} \mathrm{g}^{-1}\right)$ of chlorophyll a, chlorophyll b, total chlorophyll, carotenoids and anthocyanins, and the chlorophyll a/chlorophyll b ratio, according to the method described by Sims \& Gamon (2002).

The results were submitted to analysis of variance and the $\mathrm{F}$-test for comparison of means, and the LSD test was applied at 5\% probability. Data on percentage of phytotoxicity were transformed into arcsine/ 100 .

\section{RESULTS AND DISCUSSION}

Table 1 shows the results of the visual assessment of phytotoxicity in physic nut plants. It was observed that, from 7 DAA, all herbicide treatments had mild symptoms of plant phytotoxicity, and the symptoms gradually increased until 28 DAA. During this period, it was found that diuron $\left(2,000 \mathrm{~g} \mathrm{ha}^{-1}\right)$ and mixtures of paraquat + diuron $(200+1,000,200$ $+2,000$ and $600+2,000 \mathrm{~g} \mathrm{ha}^{-1}$ ) resulted in the highest levels of phytotoxicity, with means between 42.6 and $70.0 \%$.

There was a tendency towards reduction of phytotoxicity symptoms after 35 DAA for all treatments. The treatments with paraquat applied alone had the lowest percentages of plant injury $(\leq 0.2 \%)$, followed by the treatment with diuron $\left(1,000 \mathrm{~g} \mathrm{ha}^{-1}\right)$ and the mixture paraquat + diuron $\left(600+1,000 \mathrm{~g} \mathrm{ha}^{-1}\right)$, which showed 16.5 and $19.0 \%$ phytotoxicity, respectively.

The most severe symptoms of intoxication were observed in the application of mixtures with higher doses of diuron $\left(2,000 \mathrm{~g} \mathrm{ha}^{-1}\right)$ : witches' brooms in the apical meristem, reddish purple leaves, and chlorosis along leaf margins, which progressed to dry necrosis of these leaf margins. The application of paraquat 
Table 1 - Phytotoxicity in physic nut plants at 7, 14, 21, 28 and 35 days after herbicide application

\begin{tabular}{|c|c|c|c|c|c|c|}
\hline \multirow{3}{*}{ Treatment } & \multirow{2}{*}{ Dose } & \multicolumn{5}{|c|}{ Days after application (DAA) } \\
\hline & & 7 & 14 & 21 & 28 & 35 \\
\hline & $\left(\mathrm{g} \mathrm{ha}^{-1}\right)$ & \multicolumn{5}{|c|}{$(\%)$} \\
\hline Control & - & $0.00(0.00) \mathrm{e}$ & $0.00(0.00) \mathrm{e}$ & $0.00(0.00) \mathrm{d}$ & $0.00(0.00) \mathrm{d}$ & $0.00(0.00) \mathrm{d}$ \\
\hline Paraquat & 200 & $3.06(9.88) \mathrm{abc}$ & $10.00(14.44) \mathrm{abcd}$ & $2.13(6.10) \mathrm{cd}$ & $4.80(6.71) \mathrm{d}$ & $0.00(0.00) \mathrm{d}$ \\
\hline Paraquat & 600 & $1.66(5.53) \mathrm{d}$ & $3.73(8.23) \mathrm{cde}$ & $1.46(4.34) \mathrm{cd}$ & $8.33(13.10) \mathrm{cd}$ & $0.20(1.14) \mathrm{d}$ \\
\hline Diuron & 1.000 & $1.26(6.28) \mathrm{cd}$ & $2.46(5.72) \mathrm{de}$ & $5.40(9.52) \mathrm{bcd}$ & $26.66(24.98) b c$ & $16.50(18.46) \mathrm{c}$ \\
\hline Diuron & 2.000 & $2.33(7.52) \mathrm{bcd}$ & $8.46(15.52) \mathrm{abcd}$ & $16.33(20.24) b$ & $50.00(44.74) \mathrm{a}$ & $32.00(33.88) \mathrm{b}$ \\
\hline Paraquat + diuron & $200+1.000$ & $3.59(10.76) \mathrm{ab}$ & $9.13(16.86)$ abc & $13.33(20.72) b$ & $42.66(40.65) \mathrm{ab}$ & $31.50(33.85) b$ \\
\hline Paraquat + diuron & $200+2.000$ & $5.26(13.22) \mathrm{a}$ & $19.00(24.94) \mathrm{a}$ & $38.33(38.05) \mathrm{a}$ & $66.66(55.31) \mathrm{a}$ & $54.50(47.62) \mathrm{a}$ \\
\hline Paraquat + diuron & $600+1.000$ & $3.46(10.04) \mathrm{abc}$ & $5.93(11.95) \mathrm{bcd}$ & $8.66(14.52) b c$ & $23.33(27.23) b c$ & $19.00(20.33) \mathrm{c}$ \\
\hline Paraquat + diuron & $600+2.000$ & $4.33(11.32) \mathrm{ab}$ & $14.53(21.76) \mathrm{ab}$ & $32.00(34.20) \mathrm{a}$ & $70.00(57.21) \mathrm{a}$ & $50.50(45.29) \mathrm{ab}$ \\
\hline \multicolumn{2}{|c|}{$\mathrm{F}_{\text {(herbicides) }}$} & $8.089^{* *-1}$ & $4.443^{* *}$ & $10.063^{* *}$ & $12.478^{* *}$ & $18.149^{* *}$ \\
\hline \multicolumn{2}{|c|}{$\mathrm{F}_{\text {(blocks) }}$} & $3.487^{*}$ & $0.870^{\mathrm{ns}}$ & $0.313^{\mathrm{ns}}$ & $0.623^{\mathrm{ns}}$ & $1.085^{\mathrm{ns}}$ \\
\hline \multicolumn{2}{|c|}{ l.s.d. } & 4.023 & 10.6733 & 11.9724 & 16.9913 & 12.8706 \\
\hline \multicolumn{2}{|c|}{$\mathrm{CV}(\%)$} & 37.68 & 62.42 & 56.62 & 43.97 & 44.82 \\
\hline
\end{tabular}

Original percentage data were transformed into arcsine $+x / 100$ and are highlighted in brackets. Means followed by the same letter in the column do not differ statistically from each other by the LSD test $(\mathrm{p}<0,05) .{ }^{* *}$ significant at $1 \%$, $*$ significant at $5 \%$, ns - not significant by the F-test.

caused stem necrosis and leaf yellowing. However, these symptoms were less serious at the end of the evaluation period, and new leaves developed.

Erasmo et al. (2009) evaluated the initial tolerance of physic nut plants to preemergent and post-emergent herbicides applied alone and mixed. According to these authors, diuron $\left(2,000 \mathrm{~g} \mathrm{ha}^{-1}\right)$ applied at preemergence provided phytotoxicity of approximately $22 \%$ in plants at $12 \mathrm{DAA}$, and a reduction of phytotoxicity was observed at 20,29 and 40 DAA, with percentages of $2.3,0.0$ and $0.0 \%$, respectively.

Bonin et al. (2009) found that the application of diuron $\left(2,000 \mathrm{~g} \mathrm{ha}^{-1}\right)$ at preemergence resulted in severe symptoms of plant injury in physic nut plants and even plant death at 21 days after sowing. However, for subdoses of diuron, physic nut plants showed mild symptoms of phytotoxicity.

For dwarf castor bean crops (Maciel et al., 2008), the application of paraquat + diuron $\left(\right.$ Gramocil ${ }^{\circledR}-3.0 \mathrm{~L} \mathrm{ha}^{-1}$ ) without the use of a sprayer drift guard resulted in greater plant phytotoxicity. At 10, 20 and 30 DAA, it was observed that the plants had 51, 76 and $72 \%$ phytotoxicity for the treatment without a sprayer drift guard, respectively, and 26, 43 and
$40 \%$ for the treatment using this protective equipment.

As for morphological parameters, no significant difference was found for plant height at 35 DAA. For stem diameter, the treatment with diuron $\left(2,000 \mathrm{~g} \mathrm{ha}^{-1}\right)$ and mixtures of paraquat + diuron $(200+1,000,200$ $+2,000,600+1,000$ and $600+2,000 \mathrm{~g} \mathrm{ha}^{-1}$ ) caused reductions of $14.5,12.7,12.0,7.8$, and $13.1 \%$, respectively, compared to the control. Similarly, these treatments also affected the dry matter of leaves + petiole, stem and root, and total dry mass. The treatment with a dose of 2,000 $\mathrm{g} \mathrm{ha}^{-1}$ of diuron, alone or mixed with paraquat, caused significant reduction in the leaf area of physic nut plants (Table 2).

These results indicate that the directedspray application by the lower third of the physic nut plant can result in greater herbicide absorption by stem and basal leaves and, as a consequence, cause moderate and severe plant injury.

Peixoto et al. (2010) found that physic nut plants had impaired growth when increasing doses of diuron were applied at preemergence. This effect was more intense as the doses of diuron were inceased from 0.0 to $2,000 \mathrm{~g} \mathrm{ha}^{-1}$. 
There was no significant difference between the control and treatments with paraquat and diuron applied alone and mixed, when the concentrations of chlorophyll a and chlorophyll b were determined at 35 DAA (Table 3). However, there was a reduction in total chlorophyll and carotenoids for the mixture of paraquat + diuron $\left(600+2,000 \mathrm{~g} \mathrm{ha}^{-1}\right)$, while the other treatments did not differ from the control.

The was a reduction in anthocyanin content (Table 3) for the treatments with diuron (1,000 and 2,000 $\left.\mathrm{g} \mathrm{ha}^{-1}\right)$ and mixtures

Table 2 - Plant height (H), stem diameter (D), leaf dry mass + petiole (LDMP), stem dry mass (SDM), root dry mass (RDM), total dry mass (TDM) and leaf area (LA) at 35 days after herbicide application

\begin{tabular}{|c|c|c|c|c|c|c|c|c|}
\hline \multirow{2}{*}{ Treatment } & Dose & $\mathrm{H}$ & $\mathrm{D}$ & LDMP & SDM & RDM & TDM & LA \\
\hline & $\left(\mathrm{g} \mathrm{ha}^{-1}\right)$ & \multicolumn{2}{|c|}{$(\mathrm{cm})$} & \multicolumn{4}{|c|}{ (g) } & $\left(\mathrm{cm}^{2}\right)$ \\
\hline Control & - & 54.00 & $2.83 \mathrm{ab}$ & $30.40 \mathrm{a}$ & $61.84 \mathrm{a}$ & $37.07 \mathrm{a}$ & $129.32 \mathrm{a}$ & $3808.89 \mathrm{a}$ \\
\hline Paraquat & 200 & 54.40 & $2.96 \mathrm{a}$ & $27.91 \mathrm{ab}$ & $65.24 \mathrm{a}$ & $32.06 \mathrm{~b}$ & $125.22 \mathrm{a}$ & $3131.04 \mathrm{ab}$ \\
\hline Paraquat & 600 & 60.50 & $2.96 \mathrm{a}$ & $28.01 \mathrm{ab}$ & $67.27 \mathrm{a}$ & $36.38 \mathrm{ab}$ & $131.66 \mathrm{a}$ & $2656.99 \mathrm{abcd}$ \\
\hline Diuron & 1.000 & 59.40 & $2.70 \mathrm{bc}$ & $23.49 \mathrm{abc}$ & $44.10 \mathrm{~b}$ & $24.68 \mathrm{c}$ & $92.28 \mathrm{~b}$ & $2791.67 \mathrm{abc}$ \\
\hline Diuron & 2.000 & 52.70 & $2.42 \mathrm{~d}$ & $14.24 \mathrm{~d}$ & $33.64 \mathrm{c}$ & $21.41 \mathrm{~cd}$ & $69.30 \mathrm{~cd}$ & $1335.52 \mathrm{de}$ \\
\hline Paraquat + diuron & $200+1.000$ & 55.40 & $2.47 \mathrm{~d}$ & $16.66 \mathrm{~cd}$ & $33.25 \mathrm{c}$ & $20.51 \mathrm{~cd}$ & $70.43 \mathrm{~cd}$ & $1724.94 \mathrm{~cd}$ \\
\hline Paraquat + diuron & $200+2.000$ & 57.60 & $2.49 \mathrm{~cd}$ & $10.12 \mathrm{~d}$ & $32.69 \mathrm{c}$ & $19.55 \mathrm{~cd}$ & $62.36 \mathrm{~d}$ & $582.16 \mathrm{e}$ \\
\hline Paraquat + diuron & $600+1.000$ & 57.90 & $2.61 \mathrm{~cd}$ & $22.60 \mathrm{bc}$ & $39.39 \mathrm{bc}$ & $24.33 \mathrm{c}$ & $86.33 \mathrm{bc}$ & $2460.27 \mathrm{bcd}$ \\
\hline Paraquat + diuron & $600+2.000$ & 55.60 & $2.46 \mathrm{~d}$ & $11.32 \mathrm{~d}$ & $32.50 \mathrm{c}$ & $20.64 \mathrm{~cd}$ & $64.47 \mathrm{~d}$ & $899.74 \mathrm{e}$ \\
\hline \multicolumn{2}{|c|}{$\mathrm{F}_{\text {(herbicides) }}$} & $0.966^{\mathrm{ns}}$ & $7.679^{*}$ & $9.0180^{*}$ & $19.877^{*}$ & $18.694^{*}$ & $18.620^{* *}$ & $5.52 *$ \\
\hline \multicolumn{2}{|c|}{$\mathrm{F}_{(\text {blocks) }}$} & $0.143^{\text {ns }}$ & $0.664^{\mathrm{ns}}$ & $0.208^{\mathrm{ns}}$ & $0.388^{\mathrm{ns}}$ & $0.110^{\mathrm{ns}}$ & $0.133^{\mathrm{ns}}$ & $0.352^{\mathrm{ns}}$ \\
\hline \multicolumn{2}{|c|}{ l.s.d. } & 7.6565 & 0.2256 & 7.3176 & 9.6747 & 4.6648 & 19.34 & 1325.0675 \\
\hline \multicolumn{2}{|c|}{ CV $(\%)$} & 10.54 & 6.58 & 27.66 & 16.49 & 13.77 & 16.25 & 47.74 \\
\hline
\end{tabular}

Means followed by the same letter in the column do not differ statistically from each other by the LSD test $(\mathrm{p}<0.05)$. ${ }^{*}$ significant at $1 \%$,

* significant at $5 \%$, ns - not significant by the F-test.

Tabela 3 - Concentrations of chlorophyll a (CA), chlorophyll b (CB), total chlorophyll (TC), relação clorofila a/b (CRAB), carotenoids (C) and anthocyanins (AN) at3 5 days after herbicide application

\begin{tabular}{|c|c|c|c|c|c|c|c|}
\hline \multirow[t]{2}{*}{ Treatment } & Dose & Chlorophyll a & Chlorophyll b & $\begin{array}{c}\text { Total } \\
\text { chlorophyll }\end{array}$ & $\begin{array}{l}\text { Chlorophyll } \\
\text { a/b ratio }\end{array}$ & Carotenoids & Anthocyanin \\
\hline & $\left(\mathrm{g} \mathrm{ha}^{-1}\right)$ & \multicolumn{6}{|c|}{$\left.\mu \mu \mathrm{g} \mathrm{g}^{-1}\right)$} \\
\hline Control & - & 36.71 & 54.32 & $91.03 \mathrm{a}$ & $0.68 \mathrm{~b}$ & $45.51 \mathrm{a}$ & $205.51 \mathrm{a}$ \\
\hline Paraquat & 200 & 30.97 & 46.03 & $77.00 \mathrm{ab}$ & $0.67 \mathrm{~b}$ & $41.07 \mathrm{a}$ & $162.53 \mathrm{abc}$ \\
\hline Paraquat & 600 & 20.02 & 26.23 & $46.25 \mathrm{ab}$ & $0.82 \mathrm{~b}$ & $43.86 \mathrm{a}$ & $183.95 \mathrm{ab}$ \\
\hline Diuron & 1.000 & 21.38 & 33.30 & $54.68 \mathrm{ab}$ & $0.70 \mathrm{~b}$ & $36.55 \mathrm{a}$ & $114.99 \mathrm{bcd}$ \\
\hline Diuron & 2.000 & 23.52 & 34.92 & $58.44 \mathrm{ab}$ & $0.65 \mathrm{~b}$ & $31.87 \mathrm{ab}$ & $80.81 \mathrm{~cd}$ \\
\hline Paraquat + diuron & $200+1.000$ & 26.08 & 37.37 & $63.45 \mathrm{ab}$ & $0.80 \mathrm{~b}$ & $39.81 \mathrm{a}$ & $137.46 \mathrm{abc}$ \\
\hline Paraquat + diuron & $200+2.000$ & 39.62 & 52.49 & $92.11 \mathrm{a}$ & $0.96 \mathrm{~b}$ & $35.91 \mathrm{a}$ & $107.00 \mathrm{bcd}$ \\
\hline Paraquat + diuron & $600+1.000$ & 26.03 & 33.92 & $59.95 \mathrm{ab}$ & $0.88 \mathrm{~b}$ & $41.92 \mathrm{a}$ & $160.58 \mathrm{abc}$ \\
\hline Paraquat + diuron & $600+2.000$ & 21.38 & 17.44 & $38.83 \mathrm{~b}$ & $1.69 a$ & $20.19 \mathrm{~b}$ & $43.96 \mathrm{~d}$ \\
\hline \multicolumn{2}{|c|}{$\mathrm{F}_{\text {(herbicides) }}$} & $1.273^{\text {ns }}$ & $1.243^{\mathrm{ns}}$ & $1.222^{\mathrm{ns}}$ & $3.504^{* *}$ & $2.285^{*}$ & $2.692 *$ \\
\hline \multicolumn{2}{|c|}{$\mathrm{F}_{\text {(blocks) }}$} & $0.642^{\text {ns }}$ & $0.404^{\mathrm{ns}}$ & $0.483^{\text {ns }}$ & $0.948^{\mathrm{ns}}$ & $0.292^{\mathrm{ns}}$ & $0.343^{\text {ns }}$ \\
\hline \multicolumn{2}{|c|}{ 1.s.d. } & 17.9226 & 30.93 & 48.48 & 0.4987 & 14.7108 & 90.2861 \\
\hline \multicolumn{2}{|c|}{$\mathrm{CV}(\%)$} & 50.95 & 64.31 & 58.21 & 44.07 & 30.52 & 52.7 \\
\hline
\end{tabular}

Means followed by the same letter in the column do not differ statistically from each other by the LSD test $(\mathrm{p}<0.05)$. ${ }^{* *}$ significant at $1 \%$, * significant at $5 \%$, ns - not significant by the F-test. 
of paraquat + diuron $(200+2,000$ and $600+2,000 \mathrm{~g} \mathrm{ha}^{-1}$ ), possibly because of the synergistic effect between these herbicides inhibiting photosynthesis I and II, which eventually interfere with the synthesis and maintenance of this pigment, resulting in the reddish purple color of the leaves.

At 8 DAA, it was observed that treatments paraquat $\left(200 \mathrm{~g} \mathrm{ha}^{-1}\right)$ and paraquat + diuron (200 $+1,000$ and $600+1,000 \mathrm{~g} \mathrm{ha}^{-1}$ ) did not differ from the control as regards net photosynthesis (A). However, paraquat (600 $\left.\mathrm{g} \mathrm{ha}^{-1}\right)$ showed higher A than that of the witness, while the other treatments had reduced A. Overall, there was a reduction of net photosynthesis for treatments with diuron applied alone and mixed with paraquat for the assessed periods.

The active ingredient diuron inhibits electron transport of photosystem II (PS II) and binds to the D1 protein of the PS II reaction center, thus blocking the transfer of electrons to plastoquinone. This blockage prevents the conversion of light energy absorbed in electrochemical energy and results in the production of chlorophyll triplet and singlet oxygen which induce lipid peroxidation of the membrane and destroy the integrity of the membrane, leading to cellular disorganization (Fuerst and Norman, 1991; Breitenbach et al. 2001; Rutherford \& Krieger-Liszkay, 2001; Hiraki et al. 2003).

In contrast, paraquat, a herbicide which inhibits photosystem I, does not block the flow of electrons, but captures electrons from carriers, bypassing their normal flow, so that electrons are passed to oxygen, creating toxic forms (free radicals); these bonds break down protein and lipid membranes that lose their function and allow leakage of cell contents. Thus, tissues can be quickly affected by necrosis and induce plant death (Roman et al. 2007).

Thus, the increased dose of diuron alone and mixed with paraquat resulted in a higher level of intoxication of physic nut plants and reduced the leaf area used for the photosynthetic process, leading to low and then negative values of net photosynthesis (A) up to 31 DAA.

This indicates that physic nut plants may require more time to recover from injuries caused by diuron at the beginning of their development. Thus, this herbicide should be carefully applied in the field for weed management purposes in order to avoid contact between the herbicide and the physic nut plants, which could affect their growth.

It was also observed that the results of stomatal conductance $\left(\mathrm{g}_{\mathrm{s}}\right)$, transpiration $(\mathrm{E})$, internal $\mathrm{CO}_{2}$ concentration $(\mathrm{Ci})$ and water use efficiency (WUE) of physic nut plants, described in Tables 5, 6, 7 and 8, respectively, were similar to data obtained for A (Table 4), mainly due to the fact that these photosynthetic parameters were correlated.

In general, stomatal conductance $\left(\mathrm{g}_{\mathrm{s}}\right)$ and transpiration $(\mathrm{E})$ at $8 \mathrm{DAF}$ were not affected in most treatments, except for paraquat + diuron $\left(600+2,000 \mathrm{~g} \mathrm{ha}^{-1}\right)$, which showed, in this evaluation period, reduction in $\mathrm{g}_{\mathrm{s}}$ and $\mathrm{E}$ (Tables 5 and 6). At 16 DAA, the treatments did not differ from the control for these variables, excpet for paraquat + diuron $(200+2,000$ and $600+2,000 \mathrm{~g} \mathrm{ha}^{-1}$ ) when tarnspiraton was determined. At 23 and 35 DAA, a reduction was observed in $g_{s}$ and $E$ compared with the witness for the herbicide treatments, alone or mixed, except for paraquat (200 $\mathrm{g} \mathrm{ha}^{-1}$ ) (Tables 5 and 6).

In general, Tables 7 and 8 show that the treatments with diuron 2,000 $\mathrm{g} \mathrm{ha}^{-1}$ showed higher $\mathrm{Ci}$ and lower WUE in the evaluated periods, which is indicative of the plants' lower efficiency in converting the atmospheric $\mathrm{CO}_{2}$ into photoassimilates, as well as using water for biomass production, which corroborates the data in Tables 2 and 4.

At 23 and 31 DAA, the internal $\mathrm{CO}_{2}$ concentration ( $\mathrm{Ci})$ in the treatments with paraquat (200 and $600 \mathrm{~g} \mathrm{ha}^{-1}$ ) did not differ from that of the witness, along with diuron $(1,000$ and $\left.2,000 \mathrm{~g} \mathrm{ha}^{-1}\right)$ at 23 DAA and paraquat + diuron $\left(600+1,000 \mathrm{~g} \mathrm{ha}^{-1}\right)$, as shown in Table 7 .

For water use efficiency (WUE), the paraquat treatments $\left(200\right.$ and $\left.600 \mathrm{~g} \mathrm{ha}^{-1}\right)$ did not differ from the control at $31 \mathrm{DAA}$, while the other treatments showed a reduction in WUE (Table 8).

According to Galon et al. (2010), the photosynthetic parameters $g_{s}, E$ and WUE are 
Table 4 - Net photosynthesis (A) at 8, 16, 23 and 31 days after herbicide application

\begin{tabular}{|c|c|c|c|c|c|}
\hline \multirow{2}{*}{ Treatment } & Dose & \multicolumn{4}{|c|}{ Net photosynthesis (A) - $\mu \mathrm{mol} \mathrm{CO} \mathrm{Cm}^{-2} \mathrm{~s}^{-1}$} \\
\hline & $\left(\mathrm{g} \mathrm{ha}^{-1}\right)$ & $8 \mathrm{DAA}$ & $16 \mathrm{DAA}$ & $23 \mathrm{DAA}$ & $31 \mathrm{DAA}$ \\
\hline Control & - & $10.29 \mathrm{bc}$ & $10.97 \mathrm{ab}$ & $15.32 \mathrm{a}$ & $14.67 \mathrm{a}$ \\
\hline Paraquat & 200 & $12.13 \mathrm{ab}$ & $13.56 \mathrm{a}$ & $17.35 \mathrm{a}$ & $11.93 \mathrm{a}$ \\
\hline Paraquat & 600 & $15.21 \mathrm{a}$ & $10.32 \mathrm{ab}$ & $12.60 \mathrm{~b}$ & $11.27 \mathrm{a}$ \\
\hline Diuron & 1.000 & $4.25 \mathrm{de}$ & $2.85 \mathrm{~cd}$ & $2.27 \mathrm{~cd}$ & $0.99 \mathrm{~b}$ \\
\hline Diuron & 2000 & $1.99 \mathrm{e}$ & $0.03 \mathrm{~d}$ & $-0.40 \mathrm{e}$ & $-0.01 b$ \\
\hline Paraquat + diuron & $200+1.000$ & $6.94 \mathrm{~cd}$ & $1.27 \mathrm{~d}$ & $0.09 \mathrm{de}$ & $-0.80 \mathrm{~b}$ \\
\hline Paraquat + diuron & $200+2.000$ & $2.20 \mathrm{e}$ & $0.25 \mathrm{~d}$ & $0.21 \mathrm{de}$ & $-1.09 b$ \\
\hline Paraquat + diuron & $600+1.000$ & $8.02 \mathrm{bcd}$ & $6.54 \mathrm{bc}$ & $2.85 \mathrm{c}$ & $2.65 \mathrm{~b}$ \\
\hline Paraquat + diuron & $600+2.000$ & $1.12 \mathrm{e}$ & $-0.54 \mathrm{~d}$ & $-0.88 \mathrm{e}$ & $-0.93 \mathrm{~b}$ \\
\hline \multicolumn{2}{|c|}{$\mathrm{F}_{\text {(herbicides) }}$} & $10.555^{* *}$ & $11.843 * *$ & $69.927 * *$ & $17.588^{* *}$ \\
\hline \multicolumn{2}{|c|}{$\mathrm{F}_{\text {(blocks) }}$} & $1.415^{\mathrm{ns}}$ & $3.621 *$ & $1.407^{\mathrm{ns}}$ & $0.839^{\mathrm{ns}}$ \\
\hline \multicolumn{2}{|c|}{ l.s.d. } & 4.3864 & 4.5498 & 2.5616 & 4.407 \\
\hline \multicolumn{2}{|c|}{ CV $(\%)$} & 49.27 & 70.2 & 36.52 & 79.62 \\
\hline
\end{tabular}

Means followed by the same letter in the column do not differ statistically from each other by the LSD test $(\mathrm{p}<0.05) .{ }^{* *}$ significant at $1 \%$, * significant at $5 \%$, ns - not significant by the F-test.

Table 5 - Stomatal conductance $\left(\mathrm{g}_{\mathrm{s}}\right)$ after herbicide application

\begin{tabular}{|c|c|c|c|c|c|}
\hline \multirow{2}{*}{ Treatment } & \multirow{2}{*}{$\frac{\text { Dose }}{\left(\mathrm{g} \mathrm{ha}^{-1}\right)}$} & \multicolumn{4}{|c|}{ Stomatal conductance $(\mathrm{gs})-\mathrm{mol} \mathrm{m}^{-2} \mathrm{~s}^{-1}$} \\
\hline & & $8 \mathrm{DAA}$ & $16 \mathrm{DAA}$ & $23 \mathrm{DAA}$ & $31 \mathrm{DAA}$ \\
\hline Control & - & $0.09 \mathrm{bc}$ & $0.10 \mathrm{ab}$ & $0.13 \mathrm{~b}$ & $0.21 \mathrm{a}$ \\
\hline Paraquat & 200 & $0.11 \mathrm{abc}$ & $0.15 \mathrm{a}$ & $0.17 \mathrm{a}$ & $0.19 \mathrm{a}$ \\
\hline Paraquat & 600 & $0.20 \mathrm{a}$ & $0.08 \mathrm{ab}$ & $0.09 \mathrm{c}$ & $0.09 \mathrm{~b}$ \\
\hline Diuron & 1.000 & $0.06 \mathrm{bc}$ & $0.04 \mathrm{~b}$ & $0.02 \mathrm{de}$ & $0.04 \mathrm{~b}$ \\
\hline Diuron & 2.000 & $0.05 \mathrm{bc}$ & $0.03 \mathrm{~b}$ & $0.01 \mathrm{e}$ & $0.05 \mathrm{~b}$ \\
\hline Paraquat + diuron & $200+1.000$ & $0.09 \mathrm{bc}$ & $0.06 \mathrm{~b}$ & $0.03 \mathrm{de}$ & $0.02 \mathrm{~b}$ \\
\hline Paraquat + diuron & $200+2.000$ & $0.06 \mathrm{bc}$ & $0.02 \mathrm{~b}$ & $0.01 \mathrm{e}$ & $0.04 \mathrm{~b}$ \\
\hline Paraquat + diuron & $600+1.000$ & $0.12 \mathrm{ab}$ & $0.14 \mathrm{a}$ & $0.04 \mathrm{~d}$ & $0.04 \mathrm{~b}$ \\
\hline Paraquat + diuron & $600+1.000$ & $0.02 \mathrm{c}$ & $0.02 \mathrm{~b}$ & $0.01 \mathrm{e}$ & $0.03 \mathrm{~b}$ \\
\hline \multicolumn{2}{|c|}{$F_{(h e r b i c i d e s)}$} & $2.612^{*}$ & $3.385 * *$ & $36.674^{* *}$ & $5.697 * *$ \\
\hline \multicolumn{2}{|c|}{$F_{\text {(blocks) }}$} & $0.987^{\mathrm{ns}}$ & $3.182 *$ & $1.857^{\text {ns }}$ & $0.167^{\text {ns }}$ \\
\hline \multicolumn{2}{|c|}{ 1.s.d. } & 0.0927 & 0.0765 & 0.0281 & 0.086 \\
\hline \multicolumn{2}{|c|}{ CV $(\%)$} & 76.93 & 78.56 & 36.34 & 70.61 \\
\hline
\end{tabular}

Means followed by the same letter in the column do not differ statistically from each other by LSD test $(\mathrm{p}<0.05)$. ${ }^{* *}$ significant at $1 \%$,

* significant at $5 \%$, ns - not significant by the F-test.

efficient at identifying herbicide damage to cultivated plants, especially those affecting the photosynthetic apparatus, which indirectly influences the parameters associated with water use. Therefore, it can be inferred that diuron had negative effects on net photosynthesis, probably as a result of damage to the leaf tissue after the production of peroxides in the inhibition of electron flow in OS II, which consequently induced the production of abscisic acid (ABA) and stomatal closure, because these effects reduce stomatal conductance and $\mathrm{CO}_{2}$ in the inner space of the leaf (Zhang et al. 2001; Tironi et al. 2010). The reduction in leaf transpiration can also be a result of oxidative stress induced by the action of diuron.

The mixture of paraquat + diuron was shown to be an alternative for weed management in 
Table 6 - Transpiration (E) in physic nut plants after herbicide application

\begin{tabular}{|c|c|c|c|c|c|}
\hline \multirow{2}{*}{ Treatment } & Dose & \multicolumn{4}{|c|}{ Transpiration (E) - $\mathrm{mol} \mathrm{H}_{2} \mathrm{O} \mathrm{m}^{-2} \mathrm{~s}^{-1}$} \\
\hline & $\left(\mathrm{g} \mathrm{ha}^{-1}\right)$ & 8 DAA & $16 \mathrm{DAA}$ & $23 \mathrm{DAA}$ & $31 \mathrm{DAA}$ \\
\hline Control & - & $3.54 \mathrm{~b}$ & $1.82 \mathrm{ab}$ & $3.22 \mathrm{~b}$ & $3.47 \mathrm{a}$ \\
\hline Paraquat & 200 & $3.97 \mathrm{ab}$ & $2.43 \mathrm{a}$ & $3.97 \mathrm{a}$ & $3.22 \mathrm{a}$ \\
\hline Paraquat & 600 & $5.46 \mathrm{a}$ & $1.62 \mathrm{abc}$ & $2.52 \mathrm{c}$ & $2.01 \mathrm{~b}$ \\
\hline Diuron & 1.000 & $2.47 \mathrm{bc}$ & $1.03 \mathrm{bcd}$ & $0.77 \mathrm{de}$ & $1.14 \mathrm{bc}$ \\
\hline Diuron & 2.000 & $2.14 \mathrm{bc}$ & $0.89 \mathrm{bcd}$ & $0.45 \mathrm{e}$ & $1.09 \mathrm{bc}$ \\
\hline Paraquat + diuron & $200+1.000$ & $3.24 \mathrm{~b}$ & $1.32 \mathrm{bcd}$ & $0.93 \mathrm{de}$ & $0.68 \mathrm{c}$ \\
\hline Paraquat + diuron & $200+2.000$ & $2.20 \mathrm{bc}$ & $0.61 \mathrm{~cd}$ & $0.50 \mathrm{e}$ & $0.98 \mathrm{bc}$ \\
\hline Paraquat + diuron & $600+1.000$ & $3.27 \mathrm{~b}$ & $2.45 \mathrm{a}$ & $1.32 \mathrm{~d}$ & $1.11 \mathrm{bc}$ \\
\hline Paraquat + diuron & $600+2.000$ & $0.97 \mathrm{c}$ & $0.59 \mathrm{~d}$ & $0.38 \mathrm{e}$ & $0.74 \mathrm{c}$ \\
\hline \multicolumn{2}{|c|}{$\mathrm{F}_{\text {(herbicides) }}$} & $3.733 * *$ & $4.066^{* *}$ & $31.237 * *$ & $7.147 * *$ \\
\hline \multicolumn{2}{|c|}{$\mathrm{F}_{\text {(blocks) }}$} & $0.99^{\mathrm{ns}}$ & $4.456 * *$ & $2.327^{\mathrm{ns}}$ & $0.421^{\mathrm{ns}}$ \\
\hline \multicolumn{2}{|c|}{ 1.s.d. } & 1.9802 & 1.0204 & 0.6899 & 1.1574 \\
\hline \multicolumn{2}{|c|}{$\mathrm{CV}(\%)$} & 50.35 & 55.69 & 34.14 & 49.35 \\
\hline
\end{tabular}

Means followed by the same letter in the column do not differ statistically from each other by the LSD test (p<0.05). ** Significant at $1 \%$, ns - not significant by the F-test.

Table 7 - Internal $\mathrm{CO}_{2}$ concentration (Ci) in physic nut plants after herbicide application

\begin{tabular}{|c|c|c|c|c|c|}
\hline \multirow{2}{*}{ Treatment } & \multirow{2}{*}{$\frac{\text { Dose }}{\left(\mathrm{g} \mathrm{ha}^{-1}\right)}$} & \multicolumn{4}{|c|}{ Internal $\mathrm{CO}_{2}$ concentration $(\mathrm{Ci})-\mu \mathrm{mol} \mathrm{CO} \mathrm{Col} \mathrm{ar}^{-1}$} \\
\hline & & $8 \mathrm{DAA}$ & 16 DAA & 23 DAA & $31 \mathrm{DAA}$ \\
\hline Control & - & $160.43 \mathrm{~d}$ & $235.54 \mathrm{def}$ & $150.91 \mathrm{~cd}$ & $200.30 \mathrm{c}$ \\
\hline Paraquat & 200 & $161.24 \mathrm{~d}$ & $158.72 \mathrm{ef}$ & $174.41 \mathrm{~cd}$ & $232.48 \mathrm{c}$ \\
\hline Paraquat & 600 & $196.81 \mathrm{~d}$ & $139.36 \mathrm{f}$ & $130.07 \mathrm{~d}$ & $186.88 \mathrm{c}$ \\
\hline Diuron & 1.000 & $237.62 \mathrm{bcd}$ & $285.63 \mathrm{cde}$ & $275.28 \mathrm{bcd}$ & $406.42 \mathrm{a}$ \\
\hline Diuron & 2.000 & $310.87 \mathrm{abc}$ & $383.26 \mathrm{abc}$ & $297.12 \mathrm{bc}$ & $377.57 \mathrm{ab}$ \\
\hline Paraquat + diuron & $200+1.000$ & $214.63 \mathrm{~cd}$ & 329.67 bcd & $379.24 \mathrm{ab}$ & $403.39 \mathrm{a}$ \\
\hline Paraquat + diuron & $200+2.000$ & $341.03 \mathrm{ab}$ & $420.24 \mathrm{ab}$ & $435.69 \mathrm{ab}$ & $436.71 \mathrm{a}$ \\
\hline Paraquat + diuron & $600+1.000$ & $200.23 \mathrm{~d}$ & $276.63 \mathrm{cde}$ & $390.47 \mathrm{ab}$ & $283.64 \mathrm{bc}$ \\
\hline Paraquat + diuron & $600+2.000$ & $414.82 \mathrm{a}$ & $493.21 \mathrm{a}$ & $511.81 \mathrm{a}$ & $438.80 \mathrm{a}$ \\
\hline \multicolumn{2}{|c|}{$\mathrm{F}_{\text {(herbicides) }}$} & $5.25 * *$ & $6.99 * *$ & $5.812 * *$ & $8.816^{* *}$ \\
\hline \multicolumn{2}{|c|}{$\mathrm{F}_{\text {(blocks) }}$} & $1.41^{\mathrm{ns}}$ & $1.23^{\mathrm{ns}}$ & $2.770 *$ & $2.495^{\mathrm{ns}}$ \\
\hline \multicolumn{2}{|c|}{ l.s.d. } & 110.46 & 127.85 & 160.87 & 74.83 \\
\hline \multicolumn{2}{|c|}{$\mathrm{CV}(\%)$} & 34.49 & 32.81 & 40.94 & 23.65 \\
\hline
\end{tabular}

Means followed by the same letter in the column do not differ statistically from each other by the LSD test $(\mathrm{p}<0.05)$. $* *$ Significant at $1 \%$, * significant at $5 \%$, ns - not significant by the F-test.

physic nut crops because it has different mechanisms of action and, thus, avoids the selection of herbicide-resistant biotypes, and also explores the residual effect of diuron on soil seed bank. For herbicide applications in the field, however, the contact between the herbicides and the physic nut plants must be avoided because their growth is compromised, especially with the use of diuron.
This mixture is even more important as glyphosate-resistant weeds spread within Brazilian agriculture, as a resut of extensively using genetically modified glyphosate-tolerant varieties. Thus, the mixture paraquat + diuron may be included in integrated weed control for rotation of the mechanisms of action of herbicides, as well as control of volunteer plants, as is the case of soybean, corn, wheat and canola. 
Table 8 - Water use efficiency (WUE) in physic nut plants after herbicide application

\begin{tabular}{|c|c|c|c|c|c|}
\hline \multirow{2}{*}{ Treatment } & \multirow{2}{*}{$\frac{\text { Dose }}{\left(\mathrm{g} \mathrm{ha}^{-1}\right)}$} & \multicolumn{4}{|c|}{ Water use efficiency (WUE) - $\mathrm{mol} \mathrm{CO}_{2} \mathrm{~mol} \mathrm{H}_{2} \mathrm{O}^{-1}$} \\
\hline & & 8 DAA & $16 \mathrm{DAA}$ & $23 \mathrm{DAA}$ & $31 \mathrm{DAA}$ \\
\hline Control & - & $2.99 \mathrm{a}$ & $4.30 \mathrm{abc}$ & $4.78 \mathrm{a}$ & $5.02 \mathrm{a}$ \\
\hline Paraquat & 200 & $3.06 \mathrm{a}$ & $6.22 \mathrm{ab}$ & $4.43 \mathrm{ab}$ & $4.67 \mathrm{a}$ \\
\hline Paraquat & 600 & $2.65 \mathrm{a}$ & $6.45 \mathrm{a}$ & $4.82 \mathrm{a}$ & $4.05 \mathrm{a}$ \\
\hline Diuron & 1000 & $1.71 \mathrm{abc}$ & $2.28 \mathrm{~cd}$ & $0.97 \mathrm{abcd}$ & $-0.74 b$ \\
\hline Diuron & 2000 & $0.60 \mathrm{bcd}$ & $-0.24 \mathrm{def}$ & $-2.67 \mathrm{~d}$ & $-0.09 \mathrm{~b}$ \\
\hline Paraquat + diuron & $200+1000$ & $2.15 \mathrm{ab}$ & $1.25 \mathrm{cde}$ & $0.29 \mathrm{bcd}$ & $-1.12 b$ \\
\hline Paraquat + diuron & $200+2000$ & $0.17 \mathrm{~cd}$ & -1.18 ef & $-0.32 \mathrm{~cd}$ & $-0.13 b$ \\
\hline Paraquat + diuron & $600+1000$ & $2.44 \mathrm{a}$ & $3.00 \mathrm{bcd}$ & $2.12 \mathrm{abc}$ & $0.63 \mathrm{~b}$ \\
\hline Paraquat + diuron & $600+2000$ & $0.84 \mathrm{~d}$ & $-3.04 \mathrm{f}$ & $-3.15 d$ & $-0.29 b$ \\
\hline \multicolumn{2}{|c|}{$\mathrm{F}_{\text {(herbicides) }}$} & $5.99 * *$ & $7.01 * *$ & $4.28^{* *}$ & $4.58 * *$ \\
\hline \multicolumn{2}{|c|}{$F_{\text {(blocks) }}$} & $1.21^{\mathrm{ns}}$ & $1.44^{\mathrm{ns}}$ & $0.62^{\mathrm{ns}}$ & $0.65^{\text {ns }}$ \\
\hline \multicolumn{2}{|c|}{ l.s.d. } & 1.62 & 3.67 & 4.24 & 3.35 \\
\hline \multicolumn{2}{|c|}{$\mathrm{CV}(\%)$} & 75.70 & 122.44 & 262.43 & 195.30 \\
\hline
\end{tabular}

Means followed by the same letter in the column do not differ statistically from each other by the LSD test ( $<0.05)$. ** Significant at $1 \%$, * significant at $5 \%$, ns - not significant by the F-test.

Based on these results, it is concluded that diuron and the mixtures impaired the development and photosynthetic activity of physic nut plants in directed-spray applications, with injuries being more pronounced at doses of diuron of $2,000 \mathrm{~g} \mathrm{ha}^{-1}$. In comparison, paraquat applied alone at doses of 200 and $600 \mathrm{~g} \mathrm{ha}^{-1}$ with directed spray showed good selectivity potential for physic nut plants.

\section{LITERATURE CITED}

ARRUDA, F. P. et al. Cultivo de pinhão manso (Jatropha curcas L.) como alternativa para o semi-árido nordestino. R. Bras. Oleag. Fibr., v 8, n. 1, p. 789-799, 2004.

BREITENBACH, J.; ZHU, C.; SANDMAN, G. Bleaching herbicide norflurazon inhibits phytoene desaturase by competition with the cofactors. J. Agric. Food Chem., v. 49, n. 11, p. 5270-5272, 2001.

BONIN, F. et al. Efeitos dos herbicidas diuron e atrazina + s-metalacloro na cultura do pinhão-manso em condições de casa de vegetação. In: CONGRESSO BRASILEIRO DE PESQUISA EM PINHÃO MANSO, 1., 2009, Brasília, DF. Anais... Brasília: Embrapa Agroenergia, 2009. p. 1-3. CD-ROM

CHRISTOFFOLETI, P. J. et al. Paraquat + diuron, diquat e paraquat como alternativa de controle de buva (Conyza spp) resistente ao herbicida glyphosate na cultura de citrus. In: CONGRESSO BRASILEIRO DA CIÊNCIA DAS PLANTAS DANINHAS, 27., 2010, Ribeirão Preto. Anais... Ribeirão Preto: 2010. p. 2891-2895.
ERASMO, E. A. L. et al. Tolerância inicial de plantas de pinhão-manso a herbicidas aplicados em pré e pósemergência. Planta Daninha, v. 27, n. 3, p. 571-580, 2009.

FEY, R. et al. Determinação das principais espécies de plantas daninhas presentes no pinhão-manso e suas Interferência no número de ramos e no incremento em altura. In:

CONGRESSO BRASILEIRO DE PESQUISA EM PINHÃOMANSO, 2., 2011, Brasília. Anais... Brasília: 2011.

FUERST, E. P.; NORMAN, M. A. Interactions of herbicides with photosynthetic electron transport. Weed Sci., v. 39, n. 3, p. 458-464, 1991.

GALON, L. et al. Eficiência de uso da água em genótipos de cana-de-açúcar submetidos à aplicação de herbicidas.

Planta Daninha, v. 28, n. 4, p. 777-784, 2010.

HIRAKI, M. et al. Characterization of the alterations of the chlorophyll a fluorescence induction curve after addition of Photosystem II inhibiting herbicides. Photosynth Res., v. 78, n. 1, p. 35-46, 2003.

MACIEL, C. D. G. et al. Possibilidade de aplicação de misturas de herbicidas de ação total com jato dirigido em mamoneira de porte anão. Planta Daninha, v. 26, n. 2, p. 457-464, 2008.

NUNES, C. F. Caracterização de frutos, sementes e plântulas e cultivo de embriões de pinhão-manso (Jatropha curcas L.). 2007. 78 f. Dissertação (Mestrado em Fitotecnia) - Universidade Federal de Lavras, Lavras, 2007.

Planta Daninha, Viçosa-MG, v. 31, n. 4, p. 987-996, 2013 
OLIVEIRA, A. R.; FREITAS, S. P.; VIEIRA, H. D. Controle de Commelina benghalensis, C. Erecta e Tripogandra diuretica na cultura do café. Planta Daninha, v. 27, n. 4, p. 823-830, 2009.

PEIXOTO, M. F. S. P. et al. Ação do diuron no crescimento inicial do pinhão-manso (Jatropha curcas L.) em condições de casa de vegetação. In: CONGRESSO BRASILEIRO DE MAMONA, 4., SIMPÓSIO INTERNACIONAL DE OLEAGINOSAS ENERGÉTICAS, 1., 2010, João Pessoa. Anais... Campina Grande: Embrapa Algodão, 2010. p. 1146-1150.

RAIJ, B.van et al. Recomendações de adubação e calagem para o Estado de São Paulo. 2.ed. Campinas: Instituto Agronômico/Fundação IAC, 1997. 285 p.

(Boletim Técnico, 100).

ROMAN, E. S. et al. Como funcionam os herbicida: da biologia à aplicação. Passo Fundo: Berthier, 2007. 158 p.

RUTHERFORD, A. W.; KRIEGER-LISZKAY, A. Herbicideinduced oxidative stress in Photosystem II. Trends Biochem. Sci., v. 26, n. 11, p. 648-653, 2001.
SIMS, D. A.; GAMON, J. A. Relationships between leaf pigment content and spectral reflectance across a wide range of species, leaf structures and developmental stages. Remote Sens. Environ., v. 81, n. 2-3, p. 337-354, 2002.

SOCIEDADE BRASILEIRA DA CIÊNCIA DAS PLANTAS DANINHAS - SBCPD. Procedimentos para instalação, avaliação e análise de experimentos com herbicidas. Londrina: 1995. 42 p.

SOUZA, I. F.; MELLES C. C. A. Controle de plantas daninhas. In: RENA, A. B.; MALAVOLTA, E.; ROCHA, M.; YAMADA T. Cultura do cafeeiro: fatores que afetam a produtividade. Piracicaba: Potafós, 1986. p. 401-408.

TIRONI, S. P. et al. Alterações fisiológicas de cana-de-açúcar após a aplicação de herbicidas. In: CONGRESSO BRASILEIRO DA CIÊNCIA DAS PLANTAS DANINHAS, 28., 2010, Ribeirão Preto. Anais... Ribeirão Preto: 2010. p. 2524-2528.

ZHANG, X. et al. Hydrogen peroxide is involved in abscisic acid-induced stomatal closure in Vicia faba. Plant Physiol., v. 126, n. 4, p. 1438-1448, 2001. 